\title{
DETERMINANTS OF THE OPERATION OF POLAND'S WATER UTILITIES
}

\author{
Pawel Chudziński \\ Aquanet SA, Poznań, Poland \\ e-mail: pawel.chudzinski@aquanet.pl \\ (C) 2018 Paweł Chudziński \\ This is an open access article distributed under the Creative Commons Attribution-NonCommercial-NoDerivs license \\ (http://creativecommons.org/licenses/by-nc-nd/3.0/)
}

DOI: $10.15611 / \mathrm{ms} .2018 .1 .02$

JEL Classification: M40

\begin{abstract}
The aim of this paper is to present the situation of Polish water utilities from the perspective of cost benchmarking against the background of international experience, and to discuss the merits of using benchmarking with a view to improving water utilities efficiency. The text examines the income side of the issue by focusing on the water tariff levels used by Polish water utilities. The author's experience is that the first effects of using benchmarking in cost management are achieved after about three years of participating in benchmarking project. Another important threat is the difficulty in finding benchmarking partners or a proper benchmarking project. The third one, in the author's view the most significant, is an inadequate preparation of benchmarking indicators. The implementation of benchmarking of cost management at Aquanet SA produced measurable results, presented in this paper. It could be concluded, therefore, that using this method of cost management contributes to cost efficiency and, as a result, increases the efficiency of water utilities.
\end{abstract}

Keywords: benchmarking, water utility, efficiency, water tariffs.

\section{Introduction}

The aim of the article is to present the determinants of the effectiveness of water utilities in Poland and the presentation of the applied solutions in one of them.

Polish water utilities are subject to numerous determinants, many of which are regarded in the literature as significant for these companies' operation. Those that are relevant from a business perspective are economic, social and political considerations [Sudoł 2008]. Many of the authors who study them focus on legal and economic determinants [Rogala 2011; Bieniok 2006; Safin, Wójcik 2012] and theory of benchmarking [Zairi, Leonard 1994; Kozak, Nield 2001; Zairi 2011]. Since water supply services are provided as part of a local monopoly, it is legal determinants that are the most important. However, owing to the local character of water utilities in Poland, economic, local and ownership-related determinants are significant, too [Chudziński 2014].
The legal acts that are of crucial importance for water utilities in Poland include the Act of 7 June 2001 on the collective supply of water and the collective discharge of wastewater; the Act of 18 July 2001 - water law; and the Act on Local Government [Announcement of the Speaker of the Sejm 2015]. It should be noted that in the 1990s water companies were municipalised, which is why the vast majority of them, namely 95.4\% [IGWP 2016], are at present owned by municipalities or inter-municipal unions. An analysis of the above legal acts and of data from studies carried out by IGWP ${ }^{1}$ suggests that the overwhelming majority of water utilities in Poland are owned by municipalities and subject to these municipalities' tariff regulations.

Setting tariffs is one of the municipalities' most significant prerogatives. It is also the most important element of regulation from the viewpoint of the water utilities. Consequently, this paper discusses Poland's tariffs for collective water supply by comparing their levels in Poland and in the countries

\footnotetext{
${ }^{1}$ IGWP - "Polish Waterworks" Chamber of Commerce.
} 
represented by companies participating in the $\mathrm{EBC}^{2}$ benchmarking project ${ }^{3}$.

\section{Tariff benchmarking}

Comparability of the conditions in which companies operate is crucial to increasing efficiency by means of benchmarking. Benchmarking as a method enables us to reduce the impact of local determinants on the assessment of a company's efficiency. The area where economic and social determinants of water utilities accumulate are tariffs. Discussing Polish water utilities' tariffs will help to show the constraints which these companies have to face. Polish water utilities' tariffs are on average lower than the median tariff of water companies in Europe, as shown in Figure 1.

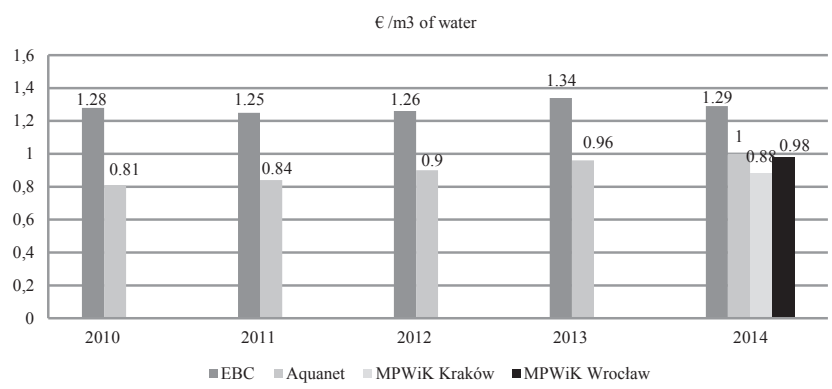

Fig. 1. The levels of water tariffs as part of the EBC project and at the selected Polish companies in 2014

Source: author's own study on the basis of [EBC 2013] $]^{4}$.

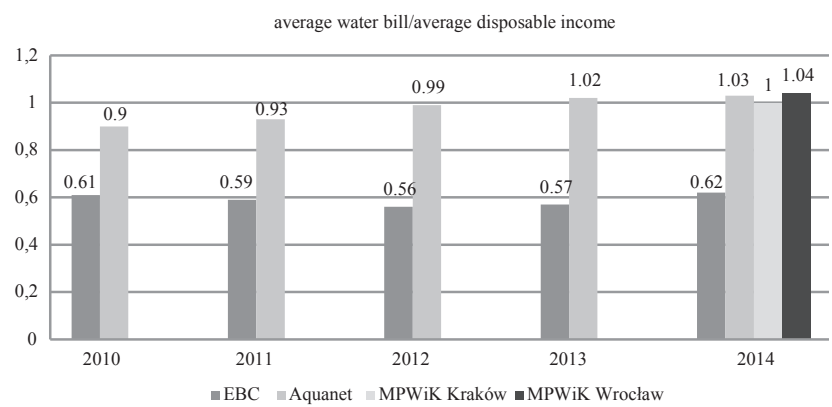

Fig. 2. Affordability of water supply services

Source: author's own study on the basis of [EBC 2013].

A characteristic feature of Polish water utilities is that they operate in a market with a relatively low level of customers' disposable income. This feature is reflected by the chart in Figure 2.

The above chart shows the affordability of water supply services understood as the share of the average water bill in relation to a family's average disposable income. A comparison of the data in Figures 1 and 2 shows that, even though Polish water utilities' tariffs are on average about $25 \%$ lower than those of their Western European counterparts, the affordability of these services is nearly half as high due to Poles' lower level of income. In turn, tariff levels in Poland to a large extent reflect the capital expenditures that Polish water utilities are obliged to make in order to adapt their infrastructure to the requirements of the Accession Treaty and, consequently, European Union law.

\section{The impact of costs on tariffs for water and sewage}

The effect of "asset-related" costs on tariff levels is presented in the graphs below.

The above charts illustrate how significantly water utilities' investment projects affect tariffs for water and sewage. As can be seen, the average contribution of asset-related costs to the water and sewage bill per person is PLN 9.35. The percentage share of these costs in the tariff is over $29 \%$. It should be noted that the Katowice company is unique in that it is located in a mining region, so given its high costs generated by mining damage, it should not be subject to this comparison. Therefore, without taking into account the Katowice utility's data, the relevant amount will be a PLN10.06 contribution of asset-related costs to the water and sewage bill per person, which means a nearly $32 \%$ contribution of these costs to the tariff for water and sewage. The impact of costs on water companies' activities was analyzed by means of benchmarking in order to achieve comparability of results. Selected results of the analyses carried out with the use of benchmarking indicators are presented below.

${ }^{2}$ EBC - European Benchmarking Cooperation. The EBC project is the only specifically international benchmarking project organized by water utility companies.

${ }^{3} \mathrm{~A}$ benchmarking project is understood as a joint effort of two or more companies aimed at carrying out benchmarking between them [Chudziński 2014].

${ }^{4}$ Aquanet SA, a water utility that operates in the area of Poznań and surrounding districts, and MWiK Kraków and MWiK Wrocław are water utilities operating in the areas of Kraków and Wrocław.

5 "Asset-related" costs are the costs of depreciation, property tax and fees for placing the infrastructure in a traffic lane, which result from possessing or having control over fixed assets. 


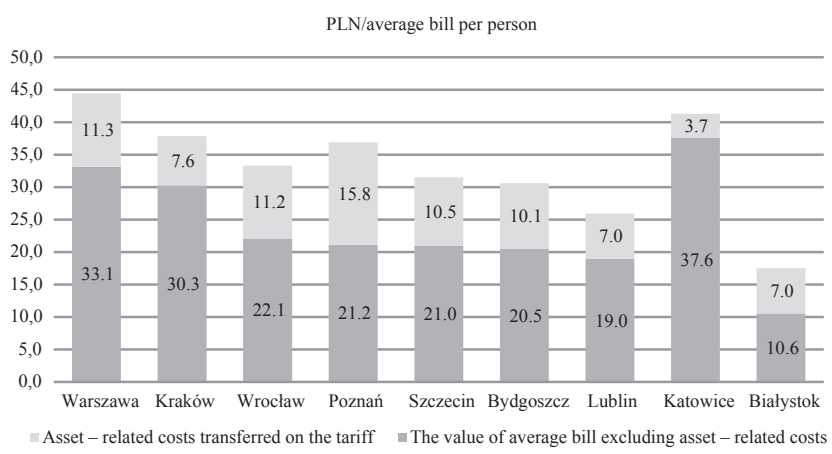

Fig. 3. The impact of asset-related costs on tariffs for water and sewage in 2014

Source: author's own study on the basis of [E\&Y 2014].

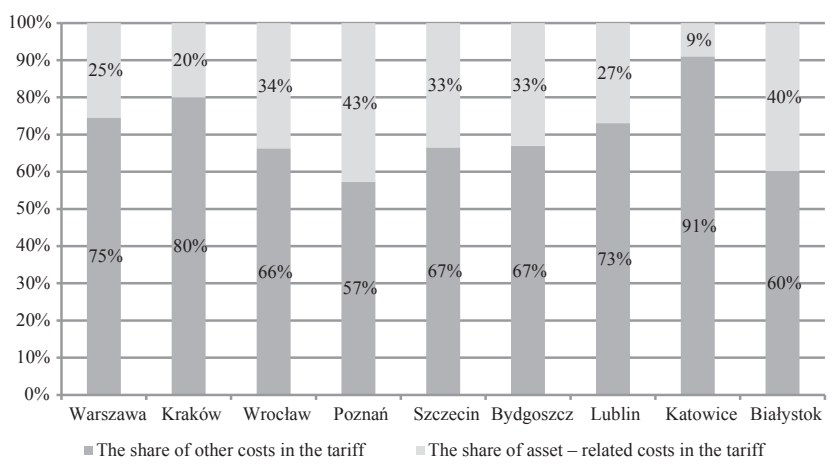

Fig. 4. The share of asset-related costs in tariffs for water and sewage in 2014

Source: author's own study on the basis of [E\&Y 2014].

\section{Costs and benchmarking indicators at Polish water utility companies}

A study to examine water utilities' costs was conducted in $2013^{6}$ on a sample of eight companies from the cities of Warsaw, Kraków, Gdańsk, Jastrzębie, Poznań, Sosnowiec, Wrocław and Zielona Góra. An in-depth survey was made using the $\mathrm{CATI}^{7}$ and $\mathrm{PAPI}^{8}$ techniques. On the basis of benchmarking indicators, the study made it possible to compare the efficiency of Polish water utilities with that of companies participating in the EBC project. Selected data collected during the study, together with a comparison of some benchmarking indicators in the IGWP project, are presented below.

On the basis of these data, it can be concluded that Polish water utilities achieve a lower level of efficiency in the above areas than companies participating in the EBC project. Hence the justification for using
Table 1. A comparison of selected benchmarking indicators of the water utilities participating in the EBC and IGWP projects

\begin{tabular}{|c|c|c|c|c|c|}
\hline Indicators & Description & 2008 & 2009 & 2010 & 2011 \\
\hline $\begin{array}{l}\text { EBC } \\
\text { employment } \\
\text { indicator }\end{array}$ & \multirow{2}{*}{$\begin{array}{l}\text { employment } \\
\text { indicator } \\
\text { (jobs/1,000 } \\
\text { homes) }\end{array}$} & 0.81 & 0.82 & 0.86 & 0.83 \\
\hline $\begin{array}{l}\text { IGWP } \\
\text { employment } \\
\text { indicator }^{\mathrm{a}}\end{array}$ & & $X$ & $X$ & $X$ & 3.54 \\
\hline \multirow{2}{*}{$\begin{array}{l}\text { Total efficiency } \\
\text { of network } \\
\text { service }\end{array}$} & \multirow{2}{*}{\begin{tabular}{|l|} 
length of water \\
supply network \\
per employee \\
(km of network/ \\
one job)
\end{tabular}} & 23.2 & 23.8 & 23.9 & 25.3 \\
\hline & & $X^{\mathrm{b}}$ & 2.7 & 3.1 & 3.1 \\
\hline $\begin{array}{l}\text { EBC energy } \\
\text { consumption } \\
\text { of water supply } \\
\text { process }\end{array}$ & \multirow{2}{*}{$\begin{array}{l}\text { electric energy } \\
\text { consumed to } \\
\text { supply water in } \\
\text { relation to } \\
\text { quantity of } \\
\text { water sold } \\
\left(\mathrm{kWh} / \mathrm{m}^{3}\right)\end{array}$} & 0.48 & $X^{\mathrm{c}}$ & $X^{\mathrm{d}}$ & 0.59 \\
\hline $\begin{array}{l}\text { IGWP energy } \\
\text { consumption } \\
\text { of water supply } \\
\text { process }\end{array}$ & & $X^{\mathrm{e}}$ & 0.82 & 0.77 & 0.73 \\
\hline $\begin{array}{l}\text { EBC failure rate } \\
\text { of water supply } \\
\text { network }\end{array}$ & \multirow{2}{*}{\begin{tabular}{|l|} 
number of \\
failures of water \\
supply network/ \\
total length of \\
water supply \\
network (no./km)
\end{tabular}} & 0.11 & 0.12 & 0.12 & 0.12 \\
\hline $\begin{array}{l}\text { IGWP failure } \\
\text { rate of water } \\
\text { supply network }\end{array}$ & & $X^{\mathrm{f}}$ & 0.66 & 0.52 & 0.31 \\
\hline
\end{tabular}

${ }^{a}$ This indicator was calculated on the basis of the performance of the seven companies investigated in the second stage of the study; ${ }^{\mathrm{b}}$ The indicator was not examined as part of the IGWP project that year; ${ }^{\mathrm{c}}$ The indicator was not examined as part of the EBC project that year; ${ }^{\mathrm{d}} \mathrm{See}$ above; ${ }^{\mathrm{e}}$ The indicator was not examined as part of the IGWP project that year; ${ }^{\mathrm{f}} \mathrm{See}$ above.

Source: [Chudziński 2014].

benchmarking in the cost management of water utilities in order to make these companies more efficient.

\section{Benchmarking cost management at Aquanet S.A.}

Aquanet S.A., a water utility that operates in the area of Poznań and surrounding districts and serves nearly 800,000 people, is the second largest water company in Poland in terms of revenue.

In 2012 , the company decided to implement a benchmarking cost management system. "It consists in analysing data obtained from benchmarking projects (including internal benchmarking), in confronting them with the company's situation while taking into account its determinants at a given time

\footnotetext{
${ }^{6}$ The study was conducted as part of a doctoral dissertation [Chudziński 2014].

${ }^{7} \mathrm{CATI}$ - computer assisted telephone interview.

${ }^{8}$ PAPI - pen and paper interview.
} 
and strategic goals, and, on the basis of these data, in taking action to reduce costs" [Chudziński 2014]. Since water utilities operate under conditions of a natural monopoly, it is difficult to determine the optimum level of their costs. This is because it is impossible to directly compare the efficiency of their operation. Different geographical and hydrological determinants, different dynamics of the investment process, and different levels of the services provided make direct comparisons between these companies impossible. There are good reasons, therefore, to use benchmarking as a basis for determining an optimum level of costs. Presented below are examples of the benchmarking indicators used by Aquanet S.A. as part of the EBC benchmarking project in which the company participates. The number of indicators concerning employment makes it possible to avoid errors of interpretation.

The first example of using benchmarking indicators in cost management, presented in the chart below, is the employment indicator in the water production process.

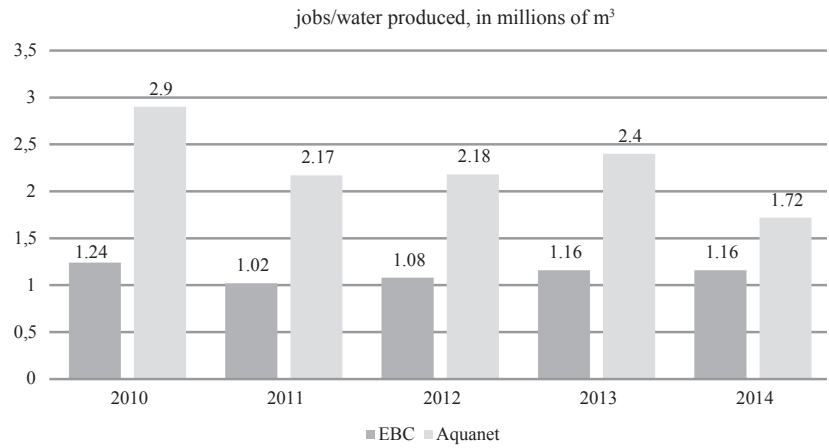

Fig. 5. The employment indicator in the water production process

Source: own study, on the basis of EBC 2015 conference proceedings.

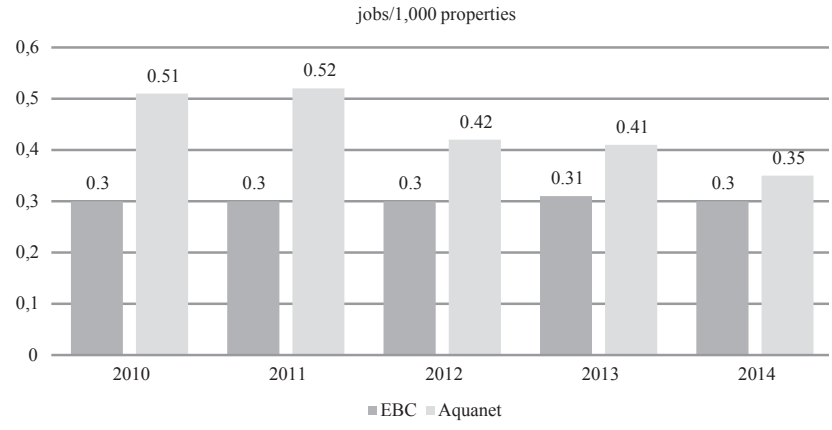

Fig. 6. The indicator of employment in relation to the number of properties served

Source: own study, on the basis of EBC 2015 conference proceedings.

Another indicator used by the companies investigated to determine their cost effectiveness is an employment indicator specifying the number of jobs in relation to the number of properties served. The indicator's trend and values over time are shown in the graph below.

While the graphs above refer to the level of employment and the related payroll costs, Figure 7 shows the efficiency of water supply network management, expressed as the number of failures in relation to the length of a water supply network.

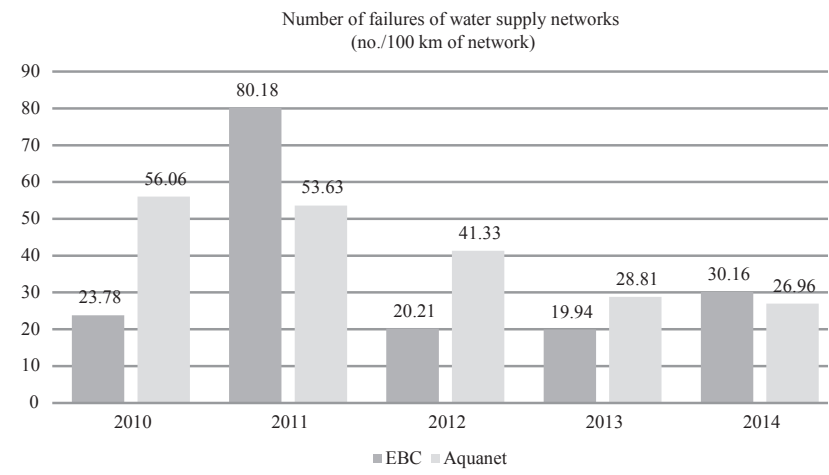

Fig. 7. The failure indicator of a water supply network

Source: own study, on the basis of EBC 2015 conference proceedings.

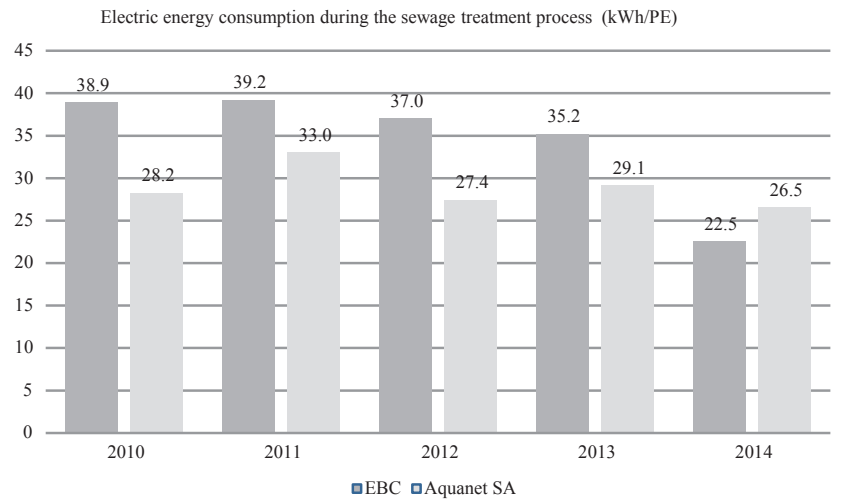

Fig. 8. The indicator of electric energy consumption during the sewage treatment process

Source: own study, on the basis of EBC 2015 conference proceedings.

The above indicator is reflected in the cost of water lost during failures and in the cost of remedying them. There is a clear trend of this indicator improving in the years 2010-2014. The 2014 level of the indicator, compared to the median of the companies participating in the EBC project was more favourable, whereas in 2010 the indicator was less than half as favourable. Parallel to the improvement in the failure indicator of a water supply network was the improvement in the indicator of electric energy consumption during the sewage treatment process, as shown in the chart below. 
From the viewpoint of cost management, the difference between this indicator's trend and the previous one is that - for the first time since such comparisons had been conducted - its value was more favourable than the average value of this indicator among the companies involved in the EBC project. However, while the comparisons were being made it turned out that the best European practices suggest that it is possible for this indicator to achieve a value of less than $15 \mathrm{kWh} / \mathrm{PE}^{9}$. The results of the company's long-term participation in the $\mathrm{EBC}$ benchmarking project have been transposed into cost management.

Cost management by means of benchmarking requires taking into account the conditions under which a company operates, including internal conditions. A significant internal determinant is the organizational changes taking place in the company itself. Highlighting the significance of the impact of such changes on the assessment of company efficiency is the following example of changes to which benchmarking indicators are subjected, and whose size depends on organizational changes rather than on changes in efficiency. In 2013, laboratory work was separated from Aquanet S.A. The influence of outsourcing on the employment indicator in the process of water quality control is shown in the chart below.

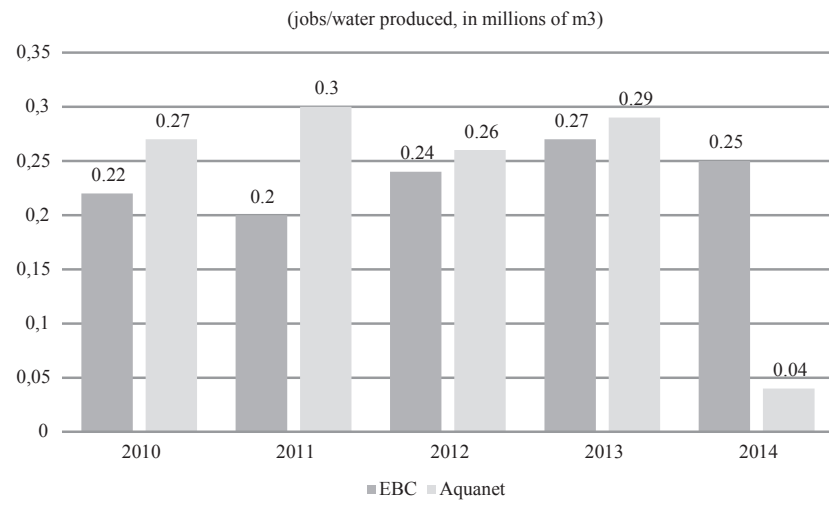

Fig. 9. The employment indicator in the process of water quality control

Source: own study, on the basis of EBC 2015 conference proceedings.

This separation was simultaneously reflected in the increased costs of external services. The unit cost of water-quality testing did not change, which is shown in the figure below.

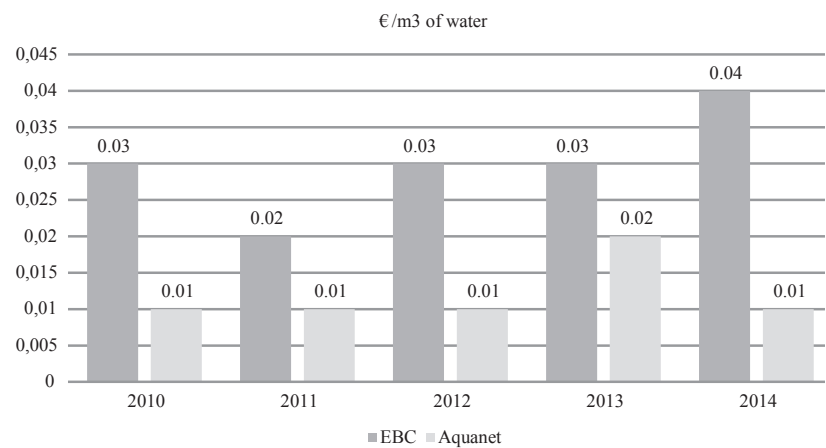

Fig. 10. Variable unit costs of water-quality testing

Source: own study, on the basis of EBC 2015 conference proceedings.

The graphs in Figures 5 and 6 point to the necessity of making a broader overview of a company's situation before interpreting data from benchmarking research. A company's local situation and regional determinants make a simple comparison of companies impossible. The data contained in the charts above suggest that outsourcing laboratory work has a significant impact on the value of the benchmarking indicator. The result of this is the simultaneous increase in the cost of external services - in this case, of laboratory services.

The implementation of benchmarking cost management at Aquanet S.A. reduced manageable costs, as shown in Table 3. For management purposes, management costs are the costs of remuneration, social insurance and other employee benefits, energy, materials and external services. The levels of particular management costs presented are adjusted for inflation ${ }^{10}$, in accordance with the principles of the company's cost optimisation programme in the years 2012-2015

The following graph presents the levels of the most important types of costs (adjusted for inflation) from the viewpoint of cost management.

On the basis of the above graph and Table 2, we can note that, after adjusting for inflation, in the years 2012-2015 management costs decreased by over 3\%. This means that cumulative costs in the period, taking 2012 as the base year, decreased by nearly PLN 15 million. It should also be noted that, during this period, the increase in Poland's average wage was higher than the inflation rate. It can be concluded, therefore, that there are good reasons for using benchmarking and benchmarking cost management in Polish water utility companies.

${ }^{9} \mathrm{PE}$ (Population Equivalent) is the number expressing the ratio of the sum of the pollution load in sewage produced during 24 hours by industrial facilities and services to the individual pollution load in household sewage produced by one person in the same period.

${ }^{10}$ The levels of costs were adjusted by the amount of inflation in a given year.

${ }^{11}$ The programme was to meet the targets of reducing costs in relation to their 2012 level. 
Table 2. Aquanet S.A.'s management costs in the years 2012-2015 (in PLN 000s)

\begin{tabular}{|r|l|r|r|r|r|}
\hline Lp. & Type of costs & \multicolumn{1}{|c|}{2012} & \multicolumn{1}{|c|}{2013} & 2014 & 2015 \\
\hline 1 & $\begin{array}{l}\text { Consumption } \\
\text { of materials }\end{array}$ & 16503 & 12880 & 12877 & 12934 \\
\hline 2 & $\begin{array}{l}\text { Consumption } \\
\text { of energy }\end{array}$ & 27265 & 24773 & 20664 & 22116 \\
\hline 3 & $\begin{array}{l}\text { External } \\
\text { transport } \\
\text { services }\end{array}$ & 689 & 654 & 684 & 884 \\
\hline 4 & $\begin{array}{l}\text { External } \\
\text { repair } \\
\text { services }\end{array}$ & 9039 & 8014 & 8097 & 8984 \\
\hline 5 & $\begin{array}{l}\text { Other } \\
\text { external } \\
\text { services }\end{array}$ & 34075 & 34544 & 39233 & 37668 \\
\hline 6 & Remuneration & 50025 & 51003 & 51260 & 51088 \\
\hline 7 & $\begin{array}{l}\text { Social } \\
\text { insurance } \\
\text { and other } \\
\text { employee } \\
\text { benefits }\end{array}$ & 10566 & 10866 & 10896 & 10802 \\
\hline 8 & $\begin{array}{l}\text { Allocations to } \\
\text { bonus funds }\end{array}$ & 2400 & 2263 & 2411 & 2470 \\
\hline 9 & $\begin{array}{l}\text { Costs of } \\
\text { business trips }\end{array}$ & 366 & 296 & 281 & 270 \\
\hline 10 & Other costs & 3280 & 3595 & 3324 & 2050 \\
\hline & TOTAL & 154207 & 148889 & 149727 & 149266 \\
\hline
\end{tabular}

Source: [Aquanet 2016].

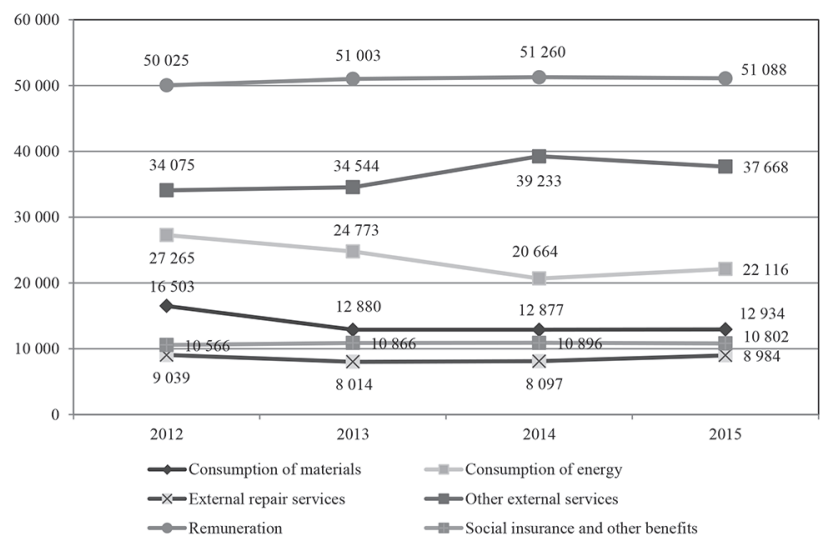

Fig. 11. Aquanet S.A.'s management costs in the years (in PLN 000's)

Source: own study, on the basis of [Aquanet 2016].

The result of such an approach to manageable costs and to those which are not regarded here as manageable costs - such as financial costs and as a results of increased tariffs - is Aquanet S.A.'s financial performance in 2012-2015, presented in the Table 3 .
Table 3. Aquanet S.A.'s financial performance in the years 2012-2015 (in PLN 000s)

\begin{tabular}{|l|c|c|c|c|c|c|}
\hline & 2010 & 2011 & 2012 & 2013 & 2014 & 2015 \\
\hline $\begin{array}{l}\text { Total } \\
\text { revenue }\end{array}$ & 338758 & 366203 & 390568 & 418137 & 440757 & 454726 \\
\hline $\begin{array}{l}\text { Net } \\
\text { financial } \\
\text { result }\end{array}$ & 9996 & 12941 & 12184 & 49478 & 59104 & 73938 \\
\hline
\end{tabular}

Source: [Aquanet 2016].

The data in Table 3 indicate that there has been a noticeable increase in the company's financial performance since 2013, which to a large extent is attributable to the implementation of the cost optimisation launched in 2012 and to benchmarking cost management.

\section{Conclusion}

Consequently, as demonstrated by comparisons of benchmarking indicators in the areas of costs of remuneration and energy consumption, Polish water utilities perform worse than the average results of companies participating in the EBC project.

Even though Polish water utilities' tariffs are, in absolute terms, lower than the average tariffs used by companies involved in the EBC project, the availability of services provided by Polish companies is noticeably lower. This is due to Polish customers' lower disposable income than in comparable Western European countries. At the same time, it is worth noting that Polish water utilities' costs are strongly increased by investment projects, which largely result from the need to adapt the quality of their services, broadly understood, to the requirements of EU law.

The implementation of benchmarking cost management at Aquanet S.A. produced measurable results presented in this paper. It could be concluded, therefore, that using this method of cost management contributes to cost efficiency and, as a result, increases the efficiency of water utilities. However, the use of benchmarking cost management involves significant threats. The most important of them is the lack or discontinuity of financial resources and time for its implementation in the company. The author's experience is that the first effects of using benchmarking in cost management are achieved after about three years of participating in a benchmarking project. Another important threat is the difficulty in finding benchmarking partners or a proper benchmarking project. A third threat, in this author's view the most significant one, is the inadequate preparation of data and the wrong interpretation of benchmarking indicators. 
Benchmarking is one of the most dynamically developing management methods in water utilities in Poland. However, too few studies on benchmarking have been conducted in Poland to be able to carry out a holistic evaluation of the water supply industry from the viewpoint of its efficiency.

\section{Bibliography}

Act of 7 June 2001 on the collective supply of water and the collective discharge of wastewater, Journal of Laws 2006.123.858.

Act of 18 July 2001, Water law, Journal of Laws 2012.145.

Announcement of the Speaker of the Parliament of the Republic of Poland of 17 September 2015 on the publication of the uniform text of the Act on Local Government, Journal of Laws 2015, item 1515.

Aquabench, http://www.aquabench.de/index_2_0_12_gb.html, date of access: 19 October 2015.

Aquanet 2016 - Aquanet SA Annual Reports 2010-2015.

Bieniok H., 2006, Uwarunkowania i problemy rozwoju przedsiębiorczości osobistej $w$ dobie gospodarki rynkowej [Determinants and problems of the development of personal entrepreneurship in the era of the market economy], [in:] K. Jaremczuk (ed), Uwarunkowania przedsiębiorczości - aspekty ekonomiczne $i$ antropologiczno-spoleczne [Determinants of entrepreneurship - economic and socio-anthropological aspects], Prof. Stanisław Tarnowski State Higher Vocational School, Tarnobrzeg.

Chudziński P., 2014, Wykorzystanie benchmarkingu w zarzadzaniu kosztami $w$ przedsiębiorstwie wodociagowym [Using benchmarking in the cost management of a water utility], doctoral dissertation, Poznań University of Economics and $\mathrm{Bu}-$ siness, Poznań.
$\mathrm{E} \& \mathrm{Y}, 2014, E \& Y$ materials prepared to conduct strategic analyses at Aquanet S.A., Warsaw.

EBC 2013-EBC 2014 conference proceedings, Antwerp 2014.

IGWP, 2016, Municipal infrastructure in 2014. The water supply industry, Polish Waterworks, Chamber of Commerce, Bydgoszcz.

Kozak M., Nield K., 2001, An Overview of Benchmarking Literature: Its Strengths and Waeknesses, [in:] P. Sungsoo (ed.), Benchmarks in Hospitality and Tourism Routledge New York, London, pp. 7-24.

OFWAT, https://www.ofwat.gov.uk/industryoverview/today/watercompanies, date of access: 19 October 2015.

Rogala K., 2011, Uwarunkowania przedsiębiorczości w obszarze mikroprzedsiębiorstw na przyktadzie miasta Leszna [Determinants of entrepreneurship in the area of micro-enterprises. The case of the city of Leszno], doctoral dissertation, Poznań University of Economics and Business, Poznań.

Safin K., Wójcik M., 2012, Uwarunkowania rozwoju przedsiębiorczości akademickiej [Determinants of the development of academic entrepreneurship], [in:] K. Jaremczuk (ed), Przedsiębiorczość - natura i atrybuty [Entrepreneurship - its nature and attributes], Prof. Stanisław Tarnowski State Higher Vocational School, Tarnobrzeg.

Sudoł S., 2008, Przedsiębiorczosśc - jej pojmowanie, typy i czynniki ja ksztaltujace [Entrepreneurship - its understanding, types and determining factors], [in:] K. Jaremczuk (ed.), Uwarunkowania przedsiębiorczości - różnorodność i zmienność [Determinants of entrepreneurship - diversity and variability], Prof. Stanisław Tarnowski State Higher Vocational School, Tarnobrzeg.

Zairi M., 2011, Benchmarking for Best Practice, Routledge, New York.

Zairi M., Leonard P., 1994, Practical Benchmarking: the Complete Guide, Chapman \& Hall, London.

\section{WYZNACZNIKI DZIALANIA PRZEDSIĘBIORSTW WODOCIĄGOWYCH W POLSCE}

Streszczenie: Celem artykułu jest zaprezentowanie sytuacji polskich przedsiębiorstw wodociągowych z perspektywy benchmarkingu na tle doświadczeń międzynarodowych oraz omówienie zalet stosowania benchmarkingu w celu poprawy efektywności tych przedsiębiorstw. Z doświadczeń autora wynika, że pierwszych efektów w zarządzaniu kosztami przez benchmarking można oczekiwać po około trzech latach uczestnictwa w projekcie benchmarkingowym. Kolejnym wyzwaniem jest znalezienie właściwych partnerów benchmarkingowych lub projektu benchmarkingowego, a przede wszystkim zapewnienie właściwej jakości i interpretacja danych płynących ze wskaźników benchmarkingowych. Zastosowanie zarządzania kosztami za pomocą benchmarkingu w Aquanet SA przyniosło wymierne efekty, można zatem stwierdzić, iż metoda ta przyczynia się do obniżenia kosztów, a w rezultacie zwiększa efektywność przedsiębiorstw wodociągowych.

Slowa kluczowe: benchmarking, przedsiębiorstwo wodociągowe, efektywność, taryfy za dostarczanie wody. 